\title{
Juvenile crime stories use police blotter without comment from suspects
}

James L. Simon

Fairfield University, jsimon@fairfield.edu

Sean Hayes

Follow this and additional works at: https://digitalcommons.fairfield.edu/english-facultypubs

Copyright 2004 Newspaper Research Journal

Archived with permission from the copyright holder.

\section{Peer Reviewed}

\section{Repository Citation}

Simon, James L. and Hayes, Sean, "Juvenile crime stories use police blotter without comment from suspects" (2004). English Faculty Publications. 48.

https://digitalcommons.fairfield.edu/english-facultypubs/48

\section{Published Citation}

Simon, James \& Hayes, Sean (2004). "Juvenile crime stories use police blotter without comment from suspects." Newspaper Research Journal, 25(4), 89-94.

This item has been accepted for inclusion in DigitalCommons@Fairfield by an authorized administrator of DigitalCommons@Fairfield. It is brought to you by DigitalCommons@Fairfield with permission from the rightsholder(s) and is protected by copyright and/or related rights. You are free to use this item in any way that is permitted by the copyright and related rights legislation that applies to your use. For other uses, you need to obtain permission from the rights-holder(s) directly, unless additional rights are indicated by a Creative Commons license in the record and/or on the work itself. For more information, please contact digitalcommons@fairfield.edu. 


\title{
Juvenile Crime Stories Use Police Blotter Without Comment from Suspects
}

\author{
By James Simon and Sean Hayes
}

$\mathrm{M}$ ore than 20 years ago, in her classic book "Crime News and the Public," Doris Graber offered a comprehensive study of the assembly line approach used by many news organizations to generate stories involving crime and violence. She concluded:

The present crime and justice format allows reporters assigned to the police beat to take police blotter news and, with minimal effort, shape it into a steady stream of "newsworthy" stories. The public wants to be entertained, primarily, and not educated and prodded into social action. ${ }^{1}$

In the two decades since Graber's seminal work, much has changed in the newspaper world. How about crime coverage and, more specifically, coverage of juvenile crime? Are young people accused of committing crimes treated evenhandedly by the press? This study examines all of the stories on juvenile justice issues in the three largest newspapers in a state, over a three-month period, to see if there is evidence of reporters going beyond the traditional police blotter approach. If only police are quoted and suspects are not given a chance to defend themselves, what does that say about the goal of newspapers to present both sides of a story?

\section{Literature Review}

News media coverage of crime has been faulted on many levels. Crime stories are seen as often focusing on single, isolated events instead of studying underlying causes or providing interpretive analysis. ${ }^{2}$ Such stories are criticized for exaggerating and sensationalizing violence and fostering stereotypes by over-representing and under-representing certain ethnic, gender and age groups. ${ }^{3}$ In the 1990 s, the news media were seen as preoccupied with crime at a time when the crime rate was declining. ${ }^{4}$ In summarizing academic studies, Dorfman concluded:

The problem is not the inaccuracy of individual stories, but that the cumulative choices of what is included in the news-or not included-presents the public with

Simon is director of the journalism program in the Department of English at Fairfield - University. Hayes was the editor of the university's student newspaper in 2002-03. The study was funded by a grant from the New England Juvenile Defender Center. 
afalse picture of higher frequency and severity of crime than is actually the case. ${ }^{5}$

Researchers have long recognized that reporters, in constructing crime stories, follow certain patterns in deciding what sources to quote. Sources with economic or political power, like police, are more likely to be quoted or to influence news. ${ }^{6}$ Official sources, such as police and government officials, are more likely to be quoted because they are easy to interview ${ }^{7}$ and because reporters feel official sources have important things to say. ${ }^{8}$ Information from government officials is more likely to be seen as factual. ${ }^{9} \mathrm{Po}$ lice have been the traditional source for most crime news. In "The Social Creation of Crime News," Sherizan writes that police

...supply reporters with a constant stream of usable crime, and this information, fitting into the work requirements of the reporters, becomes the raw material from which crime news is written. ${ }^{10}$

As a result, the "police blotter" approach to crime reporting, in which a reporter simply rewrites items from the official police log and presents them as news, has endured despite widespread criticism. In their journalism call-to-arms," The News About News: American Journalism In Peril," Leonard Downie, Jr., and Robert G. Kaiser warn:

Much bad journalism is just lazy and superficial. Newspapers fill columns with fluffy trivia and rewrites of press releases and the police blotter. ${ }^{11}$

While the assembly line approach is efficient, the short stories that result are often based on a single source and can present a narrow view of reality. Editor Jane Amari writes:

\section{Our main source for these stories} are police and court officers. Rarely do we get the side of the accused-even when attorneys permit interviews. And victims frequently want to remain in the background. ${ }^{2}$

About half of all coverage of children is related to crime and violence. ${ }^{13}$ When it comes to juvenile justice issues, the news media's routine approach to handling crime news is often combined with a sensational tone. This "wild in the streets" approach can focus on super predators or "fallen angels/little monsters," even though juvenile crime arrest trends have been stable or declining for 10 years. ${ }^{14}$ In 1998,62 percent of respondents in one poll said juvenile crime was on the rise; in reality, violent crime by youth was at its lowest point in the 25-year history of the National Crime Victimization Survey. ${ }^{15}$

This study focuses on two research questions:

RQ1:

Given past criticism of limited sourcing on police stories, what sources do present-day reporters rely on in writing juvenile justice stories? 


\section{RQ2:}

When reporters go beyond the police blotter and write longer stories, are they more likely to balance the traditional comments from police with comments from juvenile defendants and outside expert sources?

\section{Methodology}

The study focused on stories published in Connecticut's three largest newspapers-the Hartford Courant (weekday circulation 207,000), the New Haven Register $(100,000)$ and the (Bridgeport) Connecticut Post $(77,000)$ - between Jan. 1, 2002, and March 31, 2002. The study's design was based on a census of all newspaper stories, not a random sample, in the three-month period.

The study concentrated on two types of juvenile crime stories: 1) stories in which a youth, defined here as someone age 18 or younger, was in trouble with the law, or 2) stories about institutions that serve or treat such youths. Given the desire to also look at stories about institutions that serve or treat such youths, the study included stories about the state Department of Children and Families and two of its institutions, the Long Lane girls' juvenile detention center and the Connecticut Juvenile Training Center for boys.

The methodology yielded 180 news stories, those generated by both the staff and six Associated Press stories. Editorials, columns and letters to the editor were collected and noted, but they were not used in the analysis. The analysis was complicated by the Courant's practice of running a weekly police $\log$, consisting of single sentence reports on dozens of incidents. For the purposes of this study, these logs were considered a single item for a given day consisting of one paragraph. Breaking out each item in the $\log$ and treating it as a single, very short story would dramatize the use of the police blotter approach, but it would overwhelm the other stories being studied. The reader should consider, then, that dozens of additional single-item, single-source police blotter stories could have been treated individually and would have produced even more dramatic results on the lack of multiple source stories and on the short length of these crime stories.

\section{Findings}

Juvenile justice issues were a major source of news for Connecticut's three largest newspapers. Police were, by far, the most frequently quoted source; 81 percent of the stories examined included police comment (See Table 1). Other state government employees, including the governor, attorney general and legislators, were quoted in 34 percent of stories. Outside experts-such as academic experts or advocacy groups-were quoted in only 16 percent of stories. Despite the presumption of innocence until proven guilty, the point of view of the juvenile, his or her attorney and family members was included in only 8 percent of the overall stories.

The stories averaged six paragraphs in length (mean). Police were a major source for all stories in the study. In stories up to four paragraphs in 
length, police were quoted in more than 90 percent of all stories, while none of these stories included quotes from juvenile defendants and outside experts. (See Table 2) In five-to-seven paragraph stories, police were quoted in 100 percent of stories; outside experts were quoted in 9 percent of these stories and defendants in 3 percent. In 8 -to-13 paragraph stories, police again dominated, being quoted in 84 percent of stories vs. 14 percent of the stories quoting an outside expert and 14 percent quoting the juvenile defendant. Only in the longest stories-those 14 to 44 paragraphsdid the sourcing begin to even out. Both police sources and outside experts were quoted in 40 percent of the longest stories, while juvenile defendants were quoted in 15 percent.

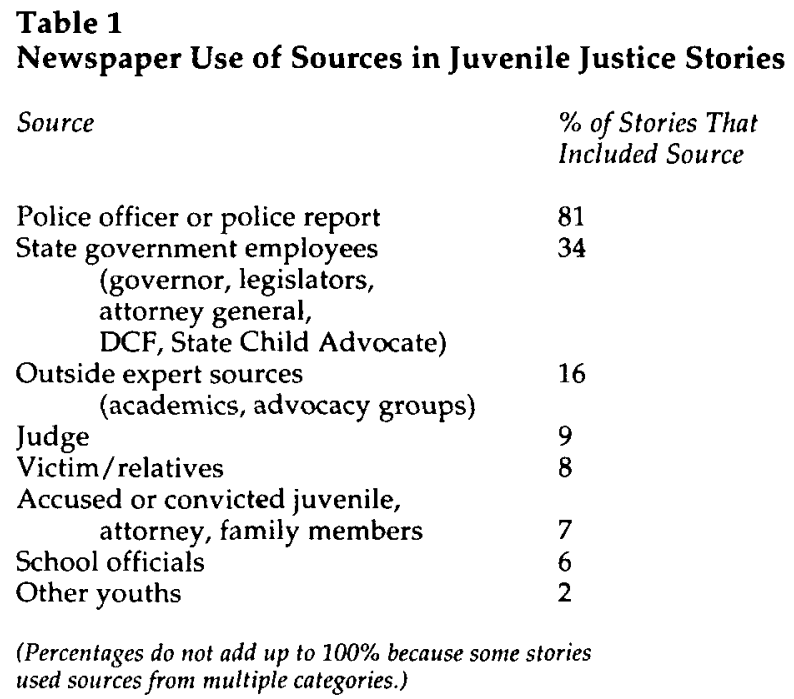

Table 1

Newspaper Use of Sources in Juvenile Justice Stories

Source

$\%$ of Stories That Included Source

Police officer or police report $\quad 81$

State government employees $\quad 34$ (governor, legislators, attorney general, DCF, State Child Advocate)

Outside expert sources (academics, advocacy groups)

Judge

im/relatives School officials Other youths 81

(Percentages do not add up to $100 \%$ because some stories used sources from multiple categories.)

\section{Discussion}

The findings are limited by the scope of this study, which focused only on juvenile justice stories in one state during a three-month period of time. The results suggest that, at least in the newspapers studied here, not much has changed since Graber first documented the shortcomings of crime reporting more than two decades ago. The economic efficiency that allows reporters to churn out stories with little effort from the police blotter has not changed. Coverage of juvenile crime issues followed the same pattern.

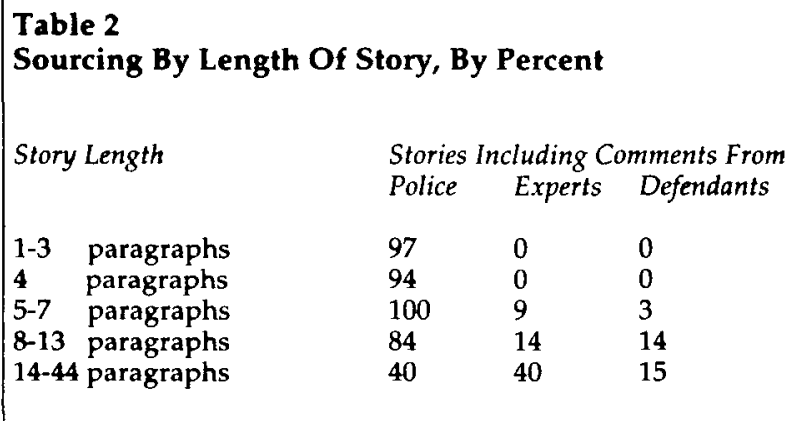


In an era of shrinking newspaper circulation and financial cutbacks, editors may be looking for even more sources of inexpensive news. If editors are satisfied with an average six-paragraph story on juvenile justice, there is not room for much other than the defendant's name, details of the crime and a reaction by police.

If reporters want to balance police comment with that of the accused, they face several hurdles. Police reports and comments are institutionalized and readily available. It is far harder to track down an accused juvenile, who may or may not want to talk, or to find out who represents the defendant. There also may be a reluctance to pursue comment from youthful suspects because of their age. But there is no legal barrier to pursuing comment; the suspect has the privilege of deciding whether to cooperate or not.

One of the most basic rules of journalism is to present the other side of the story. Yet when it comes to these juvenile crime stories, newspaperscontinue to use police blotter items without comment from suspects for the bulk of the coverage. Crime stories, especially first day stories about routine crimes, may be one of the last places in journalism where little effort is made to provide balanced sourcing.

\section{Notes}

1. Doris A. Graber, Crime news and the public. (New York: Praeger, 1980), 127.

2. Lori Dorfman and Vincent Schiraldi, OFF BALANCE: Youth, race and crime in the news, executive summary. (Washington, DC: Building Blocks for Youth/Youth Law Center, April 2001); Lynnell Hancock, "Framing children in the news: The face and color of youth crime in America," in Valerie Polakow (Ed.), The public's assault on America's children: Poverty, violence and juvenile injustice. (New York: Teachers College Press, 2002), 78-98; John McManus and Lori Dorfman, Youth violence stories focus on events, not causes. Newspaper Research Journal 23, no. 3 (fall 2002); 6-20.

3. Judy Bolch and Esther Thorson, "Teaching crime and violence reporting from a public health perspective," (paper presented at AEJMC, Miami FL, August 2001); Center for Media and Public Affairs, Crime most common story on local television news; Murders, assaults \& shootings dominate crime coverage,1996, <http:// www.cmpa.com/archive/healthtv.htm> (March 25, 2003); Dorfman and Schiraldi, OFF BALANCE: Youth, race and crime in the news.

4. Center for Media and Public Affairs, CMPA Factoids: News Agenda, 2002, <http:// www.cmpa.com/factoid/month.htm $>$ (March 25, 2003). Center for Media and Public Affairs, Crime most common story on local television news; Murders, assaults $\&$ shootings dominate crime coverage, 1996; Paul A. Perrone and Meda ChesneyLind, Representations of gangs and delinquency: Wild in the streets? Social Justice (winter 1997): 96-117; Tom Wicker and Wallace Westfeldt, Indictment: The News Media and The Criminal Justice System. Publication 98-F04. (New York: Freedom Forum/First Amendment Center, 1998).

5. Lori Dorfman. What does crime news look like-and why does it matter? In Jane Stevens, Reporting on violence: New ideas for television, print and web. (Berkeley, CA: Berkeley Media Studies Group, 2001): 13.

6. Herbert J. Gans, Deciding what's news: $A$ study of CBS Evening News, NBC Nightly News, Newsweek and Time. (New York: Pantheon Books, 1979).

7. Paula Shoemaker and Stephen D. Reese, Mediating the message: Theories of influences on mass media content. (New York: Longman, 1991); Leon V.Sigal, Reporters and officials: The organization and politics of newsmaking. (Lexington, MA: D.C. Heath, 1973).

8. David L. Paletz and Robert Entman, Media, power, politics. (New York: Free Press, 1981); Stevens, Reporting on violence: New ideas for television, print and the web.

9. Oscar H. Gandy, Beyond agenda setting: Information subsidies and public policy. (Norwood, 
NJ: Ablex, 1982); Gaye Tuchman, Making news: A study in the construction of reality. (New York: Free Press, 1978).

10. Sanford Sherizan, Social creation of crime news: All the news fitted to print. In Charles Winick (Ed.), Deviance and mass media. (Beverly Hills, CA: Sage, 1978): 203-224.

11. Leonard Downie Jr. and Robert G. Kaiser, The news about news: American journalism in peril. (New York: Vintage, 2002): 7.

12. Jane Amari, Is crime coverage out of balance? Research shows a need for more reporting of context, perspective, consequences, risk factors. (Gannett News Watch, March 1994): 2; <http:// www.gannett.com/go/newswatch/99/ march/nw0312-1.htm> (March 25, 2003).

13. Lori Dorfman, Katie Woodruff, Vivian Chavez and Lawrence Wallack, Youth and violence on local television news in California. American Journal of Public Health, 1997, 13111316; Dale Kunkel, How the news media "see" kids. Media Studies Journal, 1994, 75-84.

14. Perrone and Chesney-Lind, Representations of gangs and delinquency: Wild in the streets?

15. Dorfman and Schiraldi, OFF BALANCE: Youth, race and crime in the news. 
Copyright of Newspaper Research Journal is the property of Newspaper Research Journal and its content may not be copied or emailed to multiple sites or posted to a listserv without the copyright holder's express written permission. However, users may print, download, or email articles for individual use. 